\title{
I. On herderite, a new mineral species
}

\section{W. Haidinger Esq. F.R.S.E.}

To cite this article: W. Haidinger Esq. F.R.S.E. (1828) I. On herderite, a new mineral species, Philosophical Magazine Series 2, 4:19, 1-3, DOI: 10.1080/14786442808674700

To link to this article: http://dx.doi.org/10.1080/14786442808674700

曲 Published online: 10 Jul 2009.

Submit your article to this journal $\pi$

Џll Article views: 2

Q View related articles $\asymp$

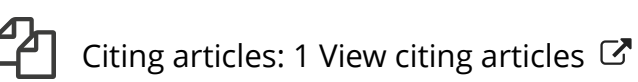


THE

PHILOSOPHICAL MAGAZINE

$A N D$

\section{ANNALS OF PHILOSOPHY.}

[NEW SERIES.]

$$
J U L Y 1828 .
$$

I. On Herderite, a new Mineral Species. By W. Haidinger, Esq. F.R.S.E.*

\section{General Description.}

TUNDAMENTAL form, a scalene four-sided pyramid, $1 \mathrm{P}=141^{\circ} 16^{\prime}, 77^{\circ} 20^{\prime}, 116^{\circ} 3^{\prime}$. (Fig. 1.) Ratio of the axes $a: b: c=1: \sqrt{ } 2 \cdot 55: \sqrt{ } 0 \cdot 46$.

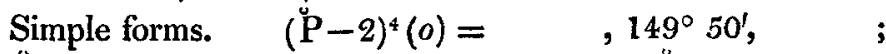
$\left(\frac{4}{3} \ddot{\mathbf{P}}-2\right)^{3}(n)=\quad, 124^{\circ} 35^{\prime}, \quad ; \mathrm{P}(p) ;(\ddot{\mathbf{P}} r+\infty)^{5}(t)=$ $115^{\circ} 7^{\prime} ;(\stackrel{\mathrm{P}}{+}+\infty)^{6}(s)=42^{\circ} 58^{\prime} ; \stackrel{\mathrm{P}}{\mathrm{P}}(\mathrm{M})=115^{\circ} b 3^{\prime} ; \stackrel{\mathrm{P}}{ } r+\infty$ $(\boldsymbol{r}) ; \overline{\mathbf{P}} r+\infty(\mathrm{P})$.

Combinations observed. 1. $\stackrel{\mathrm{P}}{r}^{r} \cdot \mathrm{P} \cdot(\stackrel{\mathrm{P}}{\mathrm{P}} r+\infty)^{5} \cdot \overline{\mathrm{P}} r+\infty$. (Fig. 2.)
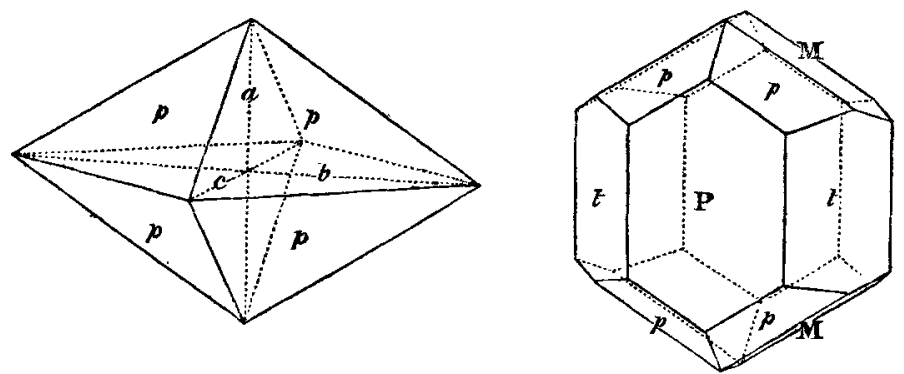

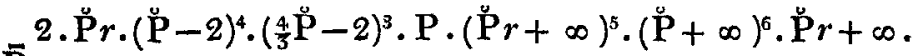
$\overline{\mathrm{P}} r+\infty$.

- Communicated by the Author.

New Series. Vol, 4. No, 19. July 1828.

B Cleavage, 
Mr. Haidinger on a nero Mineral Species (Herderite).

Cleavage distinct, parallel to the faces $\mathrm{M}$, but interrupted ; also perpendiculār to the axis, the latter only in detached portions of very, bright and even faces, and faint indications parallel to $P$. Fracture small conchoidal.

Surface, M very smooth, and delicately streaked parallel to its edges of combination with $\mathrm{P}$, and resembling in this respect all the faces of the pyramids, $n, o$, and $p$, situated between them.

The faces $r$ and $s$ are very narrow, and somewbat curved. Those marked $t$ and $\mathrm{P}$, have a peculiar granulated aspect, but they are at the same time pretty smooth, particularly the latter.

Lustre, vitreous, slightly inclining to resinous. Colour several shades of yellowish-and greenish-white; streak white, strongly translucent.

Very brittle. Hardness $=5^{\circ} \mathrm{O}$, equal to that of apatite. Specific gravity $=2 \cdot 985$.

\section{Observations.}

1. I observed and examined the characters of this species in the summer of 1823 , but deferred publishing the description of it, with a view of collecting further observations on other varieties of the same species, an expectation which was not realized. The only specimen of herderite, at present known, is in the Wernerian Museum at Freiberg. It was pointed out to me by M. Von Weissenbach, then keeper of the mu-' seum, as containing crystals, whose forms he could not exactly refer to those of apatite, among the varieties of which it was exhibited. The different aspect of the faces $p$ and $t$, the former being smooth or but faintly streaked parallel to their intersections with $\mathrm{P}$, while the latter are granulated, showed that the forms did not belong to the rhombohedral but to the prismatic system; and I did not hesitate in pronouncing the mineral to be a new species, which I requested permission to examine more minutely. This permission was very liberally conceded. Mr. Breithaupt, who was then present, and had himself at a former period placed the specimen in the cabinet of Werner, likewise concurred in acknowledging the species to be a new one.

Through the kind intercession of Mr. Reich, now keeper of the museum, I was favoured, during my stay at Berlin in the winter of 1825 , with some fragments of the specimen for analysis, by Baron Von Herder, the present Ober-Berghauptmann, or director of every thing connected with mining proceedings in Saxony. It is in compliment to that nobleman, that I propose the name of Herderite for the species; and I feel particularly gratified in thus expressing to one of my 
earliest mineralogical friends, the acknowledgement of the many instances of his having communicated to me rare specimens for examination, particularly during my stay at Freiberg.

2. Herderite occurs imbedded in fluor, in the tin mines of Ehrenfriedersdorf, in Saxony. It resembles apatite, with which it was formerly confounded, in a remarkable degree; particularly some of those named asparagus-stone: such as the variety from Zillerthal, in Salzburg, and that from Hof in Gastein in the same country, which is found accompanying the axotomous iron-ore of Mohs, and still more so certain pale greenish-white masses of the same species, which occur, though in small quantity, along with the zoisite from the Saualpe in Carinthia. The resemblance among those species is sufficient to class the herderite in the genus Fluor-haloide of Mohs, in which it may be henceforth included as the "prismati Fluor-haloide."

II. Reply of Drs. Tiedemann and Gmelin to the Remarks of Dr. Prout inserted in the Annals of Philosophy (Second Series), vol. xii. p. 405 : Communicated by Thomas Thomson, M.D. F.R.S. \& c. Regius Professor of Chemistry in the University of Glasgow.

THE more satisfied we are of the obligations which the 1 doctrine of digestion lies under to Dr. Prout, and the less intention we had to attack him unjustly, the more do we consider it as our duty to discuss the complaints which he has made, so far as we are concerned, - to defend ourselves, where we think ourselves in the right, and to acknowledge our mistakes where we think ourselves in the wrong.

Dr. Prout's complaints are the following:

1. We have led our readers to believe that Dr.Prout denies the presence of every other free acid in the contents of the stomach, except the muriatic; which is not the case.

Yet we could draw no other conclusion from Prout's paper*, than that he denied the presence of every other acid. For

a. He says (page 118), "the experiments above mentioned seemed to preclude the possibility of the presence of any destructible acid; and the only known fixed acids likely to be present were the sulphuric and phosphoric; the muriate of barytes, however, neither alone nor with the addition of ammonia, produced any immediate precipitate, showing the absence of these two acids in any sensible quantity, and still further confirming the results as before obtained."

b. Now unless the absence of other free acids be taken for

* Phillips's Annals of Philosophy, vol. viii. p. 117.

B 2

granted, 